Provided for non-commercial research and education use. Not for reproduction, distribution or commercial use.

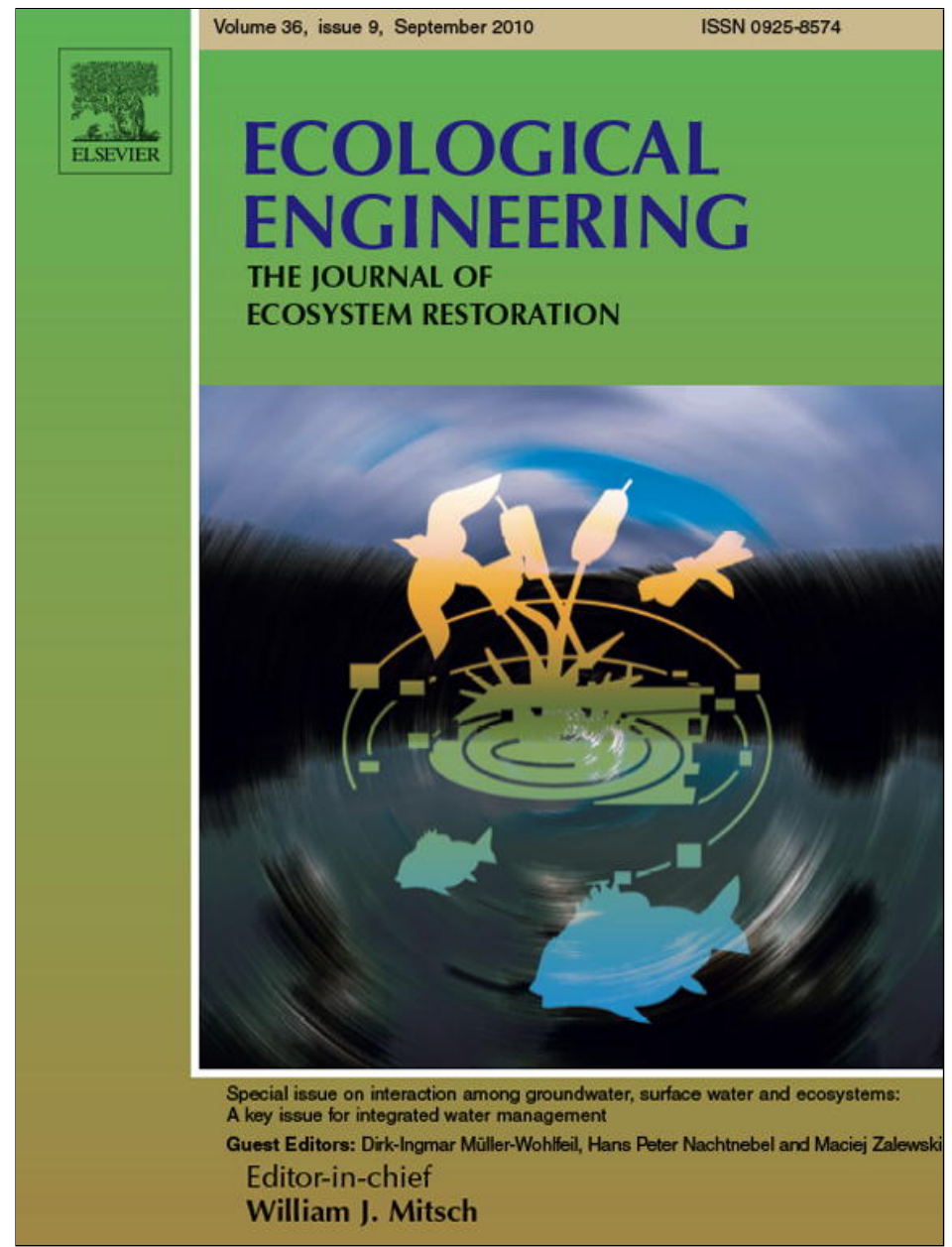

This article appeared in a journal published by Elsevier. The attached copy is furnished to the author for internal non-commercial research and education use, including for instruction at the authors institution and sharing with colleagues.

Other uses, including reproduction and distribution, or selling or licensing copies, or posting to personal, institutional or third party websites are prohibited.

In most cases authors are permitted to post their version of the article (e.g. in Word or Tex form) to their personal website or institutional repository. Authors requiring further information regarding Elsevier's archiving and manuscript policies are encouraged to visit:

http://www.elsevier.com/copyright 


\title{
An integrated model for assessing the risk of TCE groundwater contamination to human receptors and surface water ecosystems
}

\author{
Ursula S. McKnight ${ }^{\mathrm{a}, \mathrm{c}, *}$, Simon G. Funder ${ }^{\mathrm{a}}$, Jes J. Rasmussen ${ }^{\mathrm{b}}$, Michael Finkel ${ }^{\mathrm{c}}$, Philip J. Binning ${ }^{\mathrm{a}}$, \\ Poul L. Bjerg ${ }^{\mathrm{a}}$ \\ a Department of Environmental Engineering, Technical University of Denmark, Miljøvej, Building 113, 2800 Kgs. Lyngby, Denmark \\ ${ }^{\mathrm{b}}$ Department of Freshwater Ecology, National Environmental Research Institute, Århus University, Vejlsøvej 25, 8600 Silkeborg, Denmark \\ ${ }^{c}$ Center for Applied Geoscience, University of Tübingen, Sigwartstrasse 10, 72076 Tübingen, Germany
}

\section{A R T I C L E I N F O}

\section{Article history:}

Received 28 August 2009

Received in revised form 11 January 2010

Accepted 12 January 2010

\section{Keywords:}

System dynamics

Risk-based approaches

Integrated modeling

Chlorinated solvents

Uncertainty

Hyporheic zone

Contaminated sites

\begin{abstract}
A B S T R A C T
The practical implementation of the European Water Framework Directive has resulted in an increased focus on the hyporheic zone. In this paper, an integrated model was developed for evaluating the impact of point sources in groundwater on human health and surface water ecosystems. This was accomplished by coupling the system dynamics-based decision support system CARO-PLUS to the aquatic ecosystem model AQUATOX using an analytical volatilization model for the stream. The model was applied to a case study where a trichloroethylene (TCE)-contaminated groundwater plume is discharging to a stream. The TCE source will not be depleted for many decades; however, measured and predicted TCE concentrations in surface water were found to be below human health risk management targets. Volatilization rapidly attenuates TCE concentrations in surface water. Thus, only a 30-m stream reach fails to meet surface water quality criteria. An ecological risk assessment found that the TCE contamination did not impact the stream ecosystem. Uncertainty assessment revealed hydraulic conductivity to be the most important site-specific parameter. These results indicate that contaminant plumes with $\mu \mathrm{gL}^{-1}$ concentrations of TCE entering surface water systems may not pose a significant risk
\end{abstract}

(C) 2010 Elsevier B.V. All rights reserved.

\section{Introduction}

The practical implementation of the European Water Framework Directive (WFD) has generated many new challenges for water managers across Europe. As global exploitation of both stream water and groundwater increases, it is becoming more evident that managers need to develop an awareness of the linkages between these two systems, the roles that these linkages play in maintaining water quality, and how human activities may impair them (Hancock, 2002). In recognition of this, implementation of the WFD within the individual countries necessitates the evaluation of all types of contamination sources (e.g. point and diffuse) within a specific watershed in order to assess their direct impact on water quality and ecosystem health. It is required that surface water must meet good water quality and minimum ecological criteria, and that groundwater must have good chemical status.

\footnotetext{
* Corresponding author at: Department of Environmental Engineering, Technical University of Denmark, Miljøvej, Building 113, 2800 Kgs. Lyngby, Denmark. Tel.: +45 45251412; fax: +45 45932850

E-mail address: usmk@env.dtu.dk (U.S. McKnight).
}

Chlorinated solvents, such as trichloroethylene (TCE), and pesticides are among the most prevalent and serious contaminants of surface and groundwater resources in the world (e.g. Winter et al., 1998; Stroo et al., 2003; Guilbeault et al., 2005). In Denmark this is a major problem because almost all drinking water comes directly from groundwater (Henriksen et al., 2008). And many of these compounds are either acknowledged or suspected carcinogens (U.S. EPA, 2009b). Due to their widespread use, mobility and persistence, chlorinated volatile organic compounds (VOCs) are considered to have the greatest potential to discharge to surface waters (Ellis and Rivett, 2007).

Water management decisions are increasingly being based on model studies (Scholten et al., 2007) and modeling tools are becoming progressively more sophisticated, i.e. parameterized. Existing risk-based studies of coupled groundwater-surface water systems have tended to focus explicitly on predicting diffuse source transfers to surface waters (Heathwaite et al., 2005; Kannan et al., 2007). The use of these models, however, implies access to enough good quality data in order to both calibrate and validate the physical system before these models can be used in a predictive capacity. Simpler modeling approaches and tools also exist, but here the focus has typically been on either the groundwater (e.g. Troldborg et al., 2008) or the surface water system (e.g. Ani et al., 2009). 


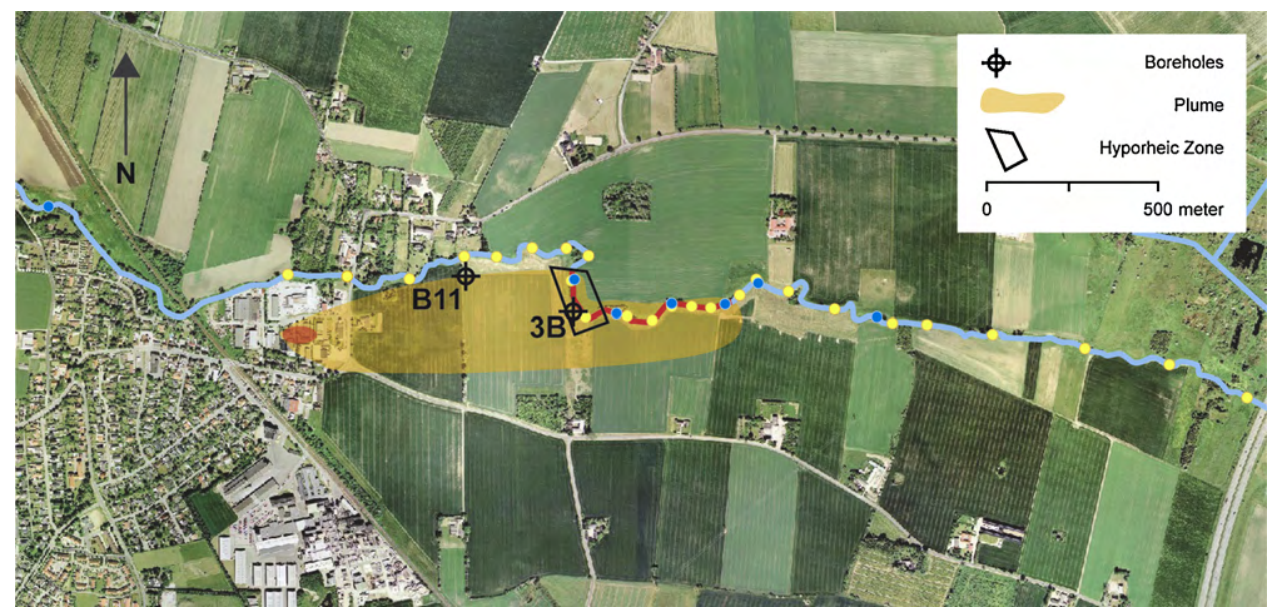

Fig. 1. Propagation of the TCE contaminant plume and impacted stream section at the Lille Skensved site. Also shown are the measurement locations in the stream (yellow dots) and stream bed (blue dots), the location of the remediation well (B11) used for pump and treat, and the location of the well in the hyporheic zone (3B). (For interpretation of the references to color in this figure legend, the reader is referred to the web version of the article.)

Risk-based approaches capable of predicting and quantifying the impacts of groundwater contamination on surface water resources and ecosystem health are currently unavailable.

This paper aimed to bridge this gap by presenting a novel riskbased, source-pathway-receptor methodology for analyzing point source impacts to both human and ecological receptors, especially for use at early decision levels. Uncertainty assessments must be incorporated into the decision-making process, with emphasis throughout the modeling process (Refsgaard et al., 2007). Thus, the proposed approach also endeavors to produce "usable" scientific information by specifically addressing the role uncertainty plays on the decision-making process, particularly with respect to the use of "effective" parameters in groundwater transport modeling.

In this paper, we show how integrated modeling can support both human health and ecological risk assessments for evaluating surface waters impacted by point sources in groundwater. This is accomplished by coupling the system dynamics-based decision support system CARO-PLUS to the process-based aquatic ecosystem model AQUATOX through a simple analytical volatilization model. The system dynamics approach implemented in CARO-PLUS (Serapiglia et al., 2005; McKnight and Finkel, 2008) is particularly suited for management issues regarding contaminated land since it has the ability to incorporate past actions (e.g. previous remedial strategies) that may have been undertaken to alleviate a problem (e.g. groundwater contamination). AQUATOX (Park et al., 2008) was found to be the most comprehensive of the few existing general ecological risk models, capable of representing the combined environmental fate and effects of toxic chemicals and their impacts to aquatic ecosystems.

\section{Case study site - Skensved stream}

A TCE contaminant plume that is leaching from groundwater into Skensved stream in Denmark is assessed with the new system dynamics tool. The Skensved stream, located on the eastern side of the island of Sjaelland in Denmark, has a catchment area of $25 \mathrm{~km}^{2}$. Lille Skensved is located in an area with protected drinking water interests. Lille Skensved Waterworks is situated approximately $1.5 \mathrm{~km}$ northwest of the town. A second well field, for Lyngen Waterworks (Christensen and Raun, 2005), lies $3 \mathrm{~km}$ east of Lille Skensved and immediately south of the Skensved stream.

The aquifer at Skensved is contaminated by TCE originating from an auto lacquer shop in Lille Skensved which has used the sol- vent for degreasing metal parts since 1974. A leaking storage tank was found in 1993 where TCE had been seeping directly into the ground below. In 2003 it was determined that this storage tank was solely responsible for the TCE contamination in the aquifer, with a plume extending up to $1000 \mathrm{~m}$ from the source area (see Fig. 1; Christensen and Raun, 2005).

The geology beneath Lille Skensved and Skensved stream consists of $2-4 \mathrm{~m}$ of alternating layers of soil, gravel, sand and clay followed by $8-10 \mathrm{~m}$ of bryozoan limestone (the Danien Limestone) that is underlain by a low permeability zone (GEO, 2009). The primary limestone aquifer is characterized by an effective hydraulic conductivity of $19 \mathrm{~m} \mathrm{~d}^{-1}$, a hydraulic gradient of 0.00473 (Christensen and Raun, 2005), and an effective porosity of 0.02 (GEO, 2009), resulting in seepage velocities on the order of $4.5 \mathrm{~m} \mathrm{~d}^{-1}$. Since no information is available on the mass fraction of organic carbon, a typical literature value of 0.002 for Danish aquifer materials was assumed (corresponding to a retardation value of 44 for TCE, Christensen et al., 1996).

Although little data exist regarding the specific source zone characteristics (e.g. geometry), measured TCE concentrations (in the $\mathrm{mgL}^{-1}$ range) in the primary aquifer below the source indicate the presence of separate phases of chlorinated solvents (Christensen and Raun, 2005). GEO (2009) estimates that 150-240 tons of TCE have been used in the auto lacquer shop during the period from 1974 to 1999. Furthermore, GEO (2009) conclude that the TCE plume is under hydraulic control through the implementation of pump and treat. Approximately $60,000-100,000 \mathrm{~m}^{3} \mathrm{yr}^{-1}$ of water have been pumped from the source area, as well as $30,000-100,000 \mathrm{~m}^{3} \mathrm{yr}^{-1}$ from well B11 (indicated in Fig. 1; Christensen and Raun, 2005; GEO, 2009). Current plans are to continue with the pump and treat strategy until 2010 (GEO, 2009).

The average water flux in the Skensved stream was determined to be $13,500 \mathrm{~m}^{3} \mathrm{~d}^{-1}\left(157 \mathrm{~L} \mathrm{~s}^{-1}\right)$, based on data taken over the past 20 years, with large interannual and seasonal variation (Christensen and Raun, 2005). In 2005, the water flow decreased from $1200 \mathrm{~L} \mathrm{~s}^{-1}$ in early January to just $6.3 \mathrm{~L} \mathrm{~s}^{-1}$ in July and August (data not shown, Bruun and Rose, 2005). The changing water flow directly affects the water levels in the stream so that, in 2005, the water depth rose to more than $50 \mathrm{~cm}$ during the winter months and dropped below $20 \mathrm{~cm}$ in the summer. In late September of 2005, water levels as low as $11 \mathrm{~cm}$ were observed.

In previous studies, conducted through the Technical University of Denmark in 2005 and 2008, the extent of groundwater-surface 
water interaction at the site has been determined using piezometers and temperature measurements. Danish groundwater usually has a temperature of $10^{\circ} \mathrm{C}$, and so a local surface water temperature rise occurs in the winter when groundwater enters the stream, as the surface water is colder than the groundwater. The reverse occurs in the summer. The measurements, taken along $4 \mathrm{~km}$ of the stream (indicated by yellow dots in Fig. 1), clearly show a temperature change in the hyporheic zone indicating that groundwater influx to the stream occurs (data not shown).

Further evidence of groundwater-surface water interaction is obtained through groundwater monitoring data. The data show that the TCE concentration in groundwater declines from the west to east side of the stream, as illustrated in Fig. 2, indicating that a significant fraction of TCE (maximum concentration of $120 \mu \mathrm{g} \mathrm{L}^{-1}$ in borehole 3B) is entering the Skensved stream. Seepage meter samplers placed in the hyporheic zone show that concentrations of up to $59 \mu \mathrm{g} \mathrm{L}^{-1}$ occur in groundwater entering the stream. The infiltration rates at three different locations along the stream were determined: $336 \mathrm{~L} \mathrm{~m}^{-2} \mathrm{~d}^{-1}$ at $1674 \mathrm{~m}, 84 \mathrm{~L} \mathrm{~m}^{-2} \mathrm{~d}^{-1}$ at $1765 \mathrm{~m}$ and $170 \mathrm{~L} \mathrm{~m}^{-2} \mathrm{~d}^{-1}$ at $1943 \mathrm{~m}$ (compare distances with Fig. 6). Based on these seepage meter measurements, the flux of contaminants from groundwater into the stream could be determined.

In the surface water in August 2005, the TCE concentration increased from zero to a maximum of $17.4 \mu \mathrm{g} \mathrm{L}^{-1}$ along a $250 \mathrm{~m}$ stretch where the groundwater plume interacts with the Skensved stream, and decreased thereafter to zero again. Thus, it was concluded that the contaminant plume enters the stream between $1625 \mathrm{~m}$ and $1875 \mathrm{~m}$. TCE was also observed in the stream on other occasions, but annual maximums occurred during the summer months.

The bottom sediments are generally highly permeable and contain insignificant amounts of organic matter. Water chemistry and redox parameters were measured in May-June 2005 using both multilevel samplers and seepage meters for the influent groundwater, as well as directly from the surface water (Table 1). Based on these results, the hyporheic zone could be characterized as being slightly aerobic and/or nitrate-reducing, thus preventing significant anaerobic dechlorination (Scheutz et al., 2008; Abe et al., 2009). No apparent increase in 1,2-cis-DCE was observed in the groundwater to the west of the stream (Figs. 1 and 2), or in the stream itself. And so it was concluded that no overall systematic degradation of TCE is taking place in the down-gradient portion of the plume.

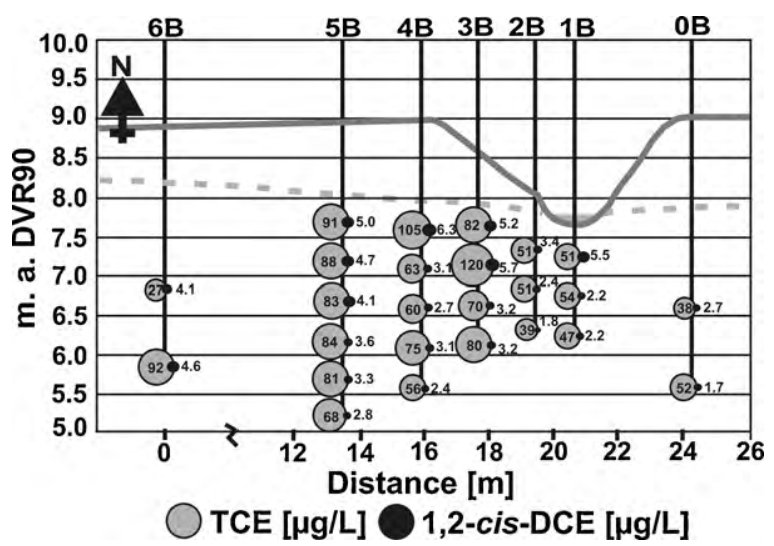

Fig. 2. TCE and 1,2-cis-DCE concentrations $\left[\mu \mathrm{g} \mathrm{L}^{-1}\right]$ in the groundwater moving west to east (left to right) from the source zone to the east bank of the Skensved stream (Christensen and Raun, 2005). Well 3B was found to contain the highest TCE concentrations, which was used for calibrating the source release model.
Table 1

Water chemistry and redox parameters measured at Skensved stream (Christensen and Raun, 2005).

\begin{tabular}{|c|c|c|c|}
\hline Parameter & $\begin{array}{l}\text { Multilevel } \\
\text { samplers }\end{array}$ & $\begin{array}{l}\text { Seepage } \\
\text { meter }\end{array}$ & $\begin{array}{l}\text { Skensved } \\
\text { stream }\end{array}$ \\
\hline $\mathrm{pH}[-]$ & $6.7-8.1$ & $6.9-7.0$ & 7.6 \\
\hline Temperature $\left[{ }^{\circ} \mathrm{C}\right]$ & $9.4-15.3$ & $10.3-13.8$ & $10.7-10.8$ \\
\hline Chloride [mg L $\mathrm{m}^{-1}$ ] & $50-278$ & $71-104$ & $24-26$ \\
\hline Oxygen $\left[\mathrm{mg} \mathrm{L}^{-1}\right]$ & $0.2-3.5$ & $0.3-0.5$ & 8.5 \\
\hline Nitrate [mg N L $\left.{ }^{-1}\right]$ & $0.4-6.4$ & $1.8-2.0$ & $1.8-1.9$ \\
\hline Dissolved Iron [mg L-1 & $<0.3-1.2$ & n.a. & n.a. \\
\hline Sulphate $\left[\mathrm{mg} \mathrm{S} \mathrm{L}^{-1}\right]$ & $7-41$ & $14-17$ & $9-10$ \\
\hline
\end{tabular}

\section{Methodology: integrated modeling framework}

The impacts of TCE on Skensved stream was assessed using a source-pathway-receptor concept (see Fig. 3). The conceptual model was implemented by coupling the system dynamics model CARO-PLUS to the U.S. EPA ecological impact assessment model AQUATOX. This was necessary since CARO-PLUS is currently equipped only for the analysis of risks to human health, specifically when the contamination plume at the receptor occurs in groundwater (note however that the source zone can originate either in soil, groundwater or both). Similarly, the U.S. EPA model AQUATOX is equipped only for the analysis of ecological effects on aquatic ecosystems when the contaminants are already present in the surface water.

In order to enable both a quantitative human health risk assessment and an ecological risk assessment of this site, the decision support system CARO-PLUS was coupled to the process-based aquatic ecosystem model AQUATOX through a simple analytical surface water volatilization model. The model was constructed in order to track the fate of TCE as it moves from the groundwater through the groundwater-surface water interaction zone (i.e. hyporheic zone) into surface water. These steps will be described in more detail in the following sections.

\subsection{System dynamics modeling: CARO-PLUS}

CARO-PLUS, developed at the Center for Applied Geoscience/University of Tübingen, is intended to be used for preliminary assessment as part of a tiered approach, and to allow the user to simulate and optimize the effects of potential remedial actions including tackling the contaminant source and managing groundwater plumes (McKnight, 2009). It currently consists of a source release module, a contaminant transport module and a human health impact assessment module. Both mass release and contaminant transport in groundwater are quantified using transient models that are based on analytical approaches (Sauty, 1980; Huntley and Beckett, 2002; Eberhardt and Grathwohl, 2002; Peter et al., 2008). The existing contamination and its further development can be evaluated on the basis of contaminant mass fluxes, concentrations, and risk indices (carcinogenic/non-carcinogenic). Possible remedial actions causing mass flux changes over time are also simulated (McKnight, 2009).

CARO-PLUS also contains a risk assessment module that describes exposure pathways, i.e. transport (transfer) of contaminants from groundwater to the receptor "human being", in accordance to the Multimedia Environmental Pollutant Assessment System developed by Strenge and Smith (2006). The model is capable of analyzing pollutant behavior in various media (air, soil, groundwater and surface water) and estimating transport through and between media. The uncertainty inherent in both site-specific and exposure parameters is explicitly taken into account using Monte-Carlo simulations. 


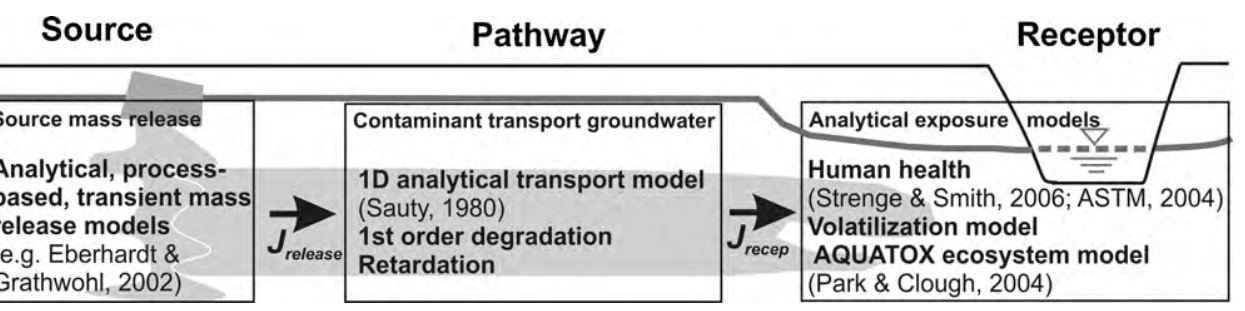

Fig. 3. Schematic illustration of the source-pathway-receptor concept implemented in the program CARO-PLUS.

CARO-PLUS is built on the system dynamics platform Vensim (Ventana Systems, 2007). System dynamics uses an interlinked system of stocks (levels) and flows (rates). Water, as well as contaminant mass can be thought of and measured using stock terms, which describe the volume or mass present at a particular place and point in time. Similarly, water and mass transfer can be calculated using flow terms, which describe the volume or mass reaching or passing a defined point or area in a given time period. The overall structure of the model as implemented in a systems dynamics framework is described in Fig. 4. The stocks are represented in the figure using boxes and the flows by double arrows. The single arrow terms show the most important inputs required in calculations. The model has been tested for appropriateness and verified in McKnight (2009).

\subsubsection{Source characterization: contaminant emission from DNAPL pool}

The source model conceptually distinguishes between light and dense NAPL contamination scenarios, as well as residual phase or blob zones. The organic contaminant phase is typically described as a mixture of multiple compounds, but single compound scenarios can also be modeled. Mass release from a DNAPL pool is quantified using a model which describes the dispersive mass transfer of DNAPL into groundwater flowing across the pool, with the resultant flux being given by (Eberhardt and Grathwohl, 2002):

$J_{i}^{\text {dnapl }}=C_{w, i}^{\text {sat }} B_{p} L_{p} n_{e} \sqrt{\frac{4 D v_{x}}{\pi L_{p}}}$ where $J_{i}^{\text {dnapl }}\left[\mathrm{M} \mathrm{T}^{-1}\right]$ is the dissolution rate of compound $i$ from a pool with width $B_{p}[\mathrm{~L}]$ and length $L_{p}[\mathrm{~L}]$, and $D\left[\mathrm{~L}^{2} \mathrm{~T}^{-1}\right]$ is the transverse vertical hydrodynamic dispersion coefficient, which is calculated using:

$D=D_{p}+\alpha_{t v} v_{x}$

where $D_{p}\left[\mathrm{~L}^{2} \mathrm{~T}^{-1}\right]$ is the pore diffusion coefficient (also approximated as $D_{a q} n_{e}$ ) and $\alpha_{t v}[\mathrm{~L}]$ is the transverse vertical dispersivity.

The values for transverse vertical dispersivity are estimated by assuming that dispersion can be represented as a linear function of groundwater pore velocity (Klenk and Grathwohl, 2002). Other assumptions inherent to this solution include constant concentration at the NAPL-water interface where dissolution occurs, and equilibrium is assumed to have been reached between the NAPL and a boundary layer of water (i.e. bordering the DNAPL pool).

\subsubsection{Groundwater contaminant transport}

The mass transfer of the contaminant from the source to the stream is modeled analytically, assuming steady-state (averaged) flow conditions, advective and diffusive transport, retardation and biodegradation (i.e. when applicable) by (Sauty, 1980):

$J_{R}=\frac{J_{S E}}{2} \operatorname{erfc}\left(\frac{L_{x}-v_{x, R} t_{R}}{2 \sqrt{\alpha_{L} v_{x, R} t_{R}}}\right) e^{-\lambda_{i} L_{x} / v_{x}}$

where $J_{R}\left[\mathrm{M} \mathrm{T}^{-1}\right]$ is the estimated mass flux at the receptor, $J_{S E}$ $\left[\mathrm{MT}^{-1}\right]$ is the mass flux at the down-gradient edge of the source, $L_{X}[\mathrm{~L}]$ is the distance between the source and the receptor in the $x$-direction, $\alpha_{L}[\mathrm{~L}]$ is the longitudinal dispersivity, $t_{R}[\mathrm{~T}]$ is the sim-

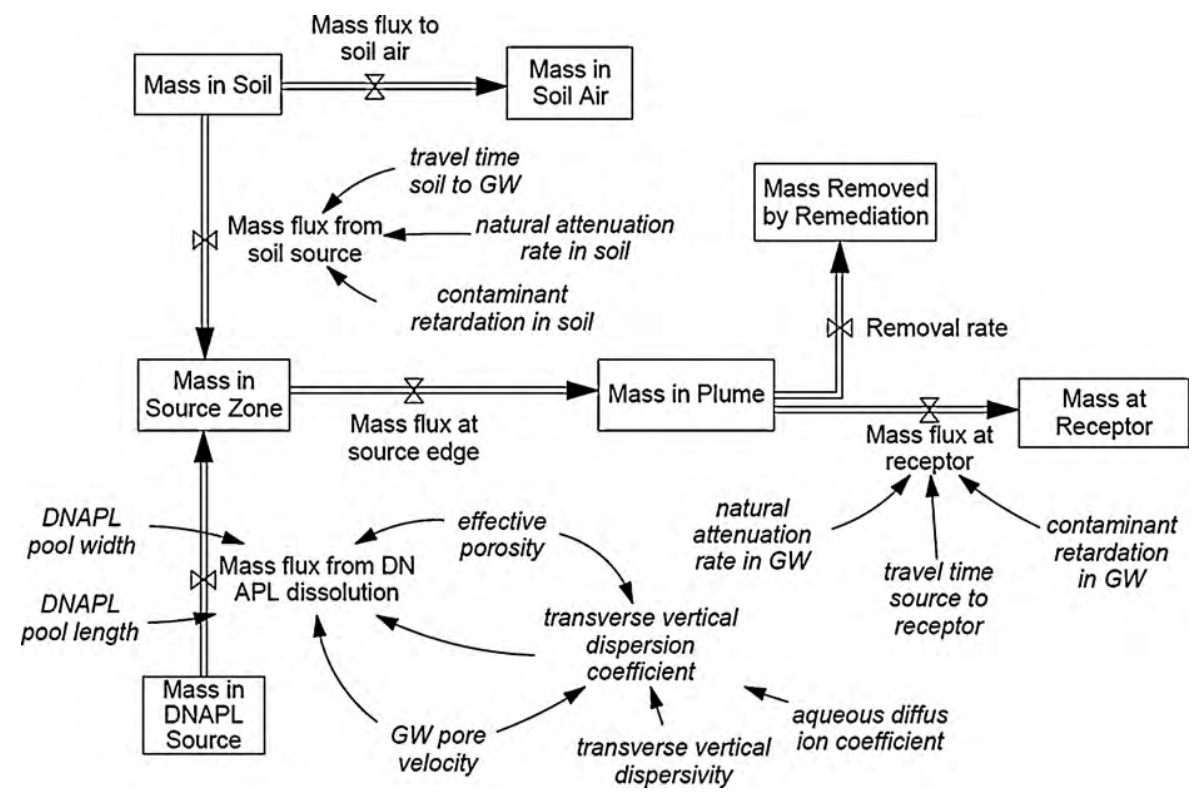

Fig. 4. Major structure for the DNAPL pool release scenario and transport along the groundwater pathway, including retardation and degradation. 
ulation time, $\lambda_{i}\left[\mathrm{~T}^{-1}\right]$ is the first-order biodegradation rate for compound $i$ and $v_{x}\left[\mathrm{LT}^{-1}\right]$ is the groundwater pore velocity. The parameter values employed are the average (or effective) values for the pathway between the source and receptor. The longitudinal dispersivity is directly estimated in CARO-PLUS by (Xu and Eckstein, 1995):

$\alpha_{L}=0.83\left[\log \left(L_{X}\right)\right]^{2.414}$

\subsection{Analytical volatilization model}

A stream transport model is developed to describe the transfer of mass into the stream from groundwater and the subsequent volatilization of contaminant from the stream. The model is based on the observation that volatilization is likely to be the dominant process affecting the concentration of VOCs in stream water (Rathbun, 2000).

The model considers a stream of constant volume, where inflow equals the outflow. The change in concentration of a VOC over time for a given volume of water is given by:

$V \frac{d C(t)}{d t}=Q_{g w} C_{g w}-K_{v} C(t) V$

where $V\left[\mathrm{~L}^{3}\right]$ is the volume of the water body, $\mathrm{Q}_{g w}\left[\mathrm{~L}^{3} \mathrm{~T}^{-1}\right]$ and $C_{g w}\left[\mathrm{ML}^{-3}\right]$ are the flux and VOC concentration of the infiltrating groundwater, respectively, $K_{v}\left[\mathrm{~T}^{-1}\right]$ is the volatilization rate and $C(t)\left[\mathrm{M} \mathrm{L}^{-3}\right]$ is the VOC concentration at time $t$ [T]. If the initial VOC concentration is $C(0)=0$, then the solution of $(5)$ is given by:

$C(t)=\frac{C_{g w} Q_{g w}}{K_{v} V}-\frac{e^{-K_{\nu} t} C_{g w} Q_{g w}}{K_{v} V}$

When the initial VOC concentration is not zero, the solution becomes:

$C(t)=\frac{C_{g w} Q_{g w}}{K_{v} V}+e^{-K_{v} t}\left(C_{t-1}-\frac{C_{g w} Q_{g w}}{K_{v} V}\right)$

where $C_{t-1}\left[\mathrm{M} \mathrm{L}^{-1}\right]$ is the initial VOC concentration. Eq. (7) can be used for scenarios where the infiltration rates $Q_{g w}$ and/or the VOC groundwater concentrations $C_{g w}$ are not constant over the distance of the modeled stream.

\subsection{Risk assessment}

\subsubsection{Human health risk assessment}

The risk to human health due to direct or indirect exposure to contaminated water (e.g. ingestion of water or leafy vegetables) can be assessed using a methodology that is applicable to both groundwater and surface water. In CARO-PLUS, the risk assessment is focused on the risks associated with pollutants originating in groundwater. Here the human health risk assessment was extended to also consider surface water contaminants. The risk assessment begins with identified concentrations of the constituents of interest which are then converted to average daily doses at the point of exposure (e.g. receptor location in Fig. 3). The doses are then converted to risk values for either carcinogens (evaluated as total risk level, $R L_{t o t, i}[-]$ ) or non-carcinogens (total hazard quotient, $\left.H Q_{t o t, i}[-]\right)$ using:

$$
\begin{aligned}
R L_{\text {tot }, i} & =\sum_{k=1}^{n_{E}} L A D D_{i} \times S F_{i} \\
H Q_{\text {tot }, i} & =\sum_{k=1}^{n_{E}} \frac{C A D D_{i}}{R f D_{i}}
\end{aligned}
$$

where $L A D D_{i}\left[\mathrm{M} \mathrm{M}^{-1} \mathrm{~T}^{-1}\right]$ is the lifetime (cancer) average daily dose, $S F_{i}\left[\mathrm{M} \mathrm{M}^{-1} \mathrm{~T}^{-1}\right]^{-1}$ is the corresponding (oral) slope factor, $k$ is the exposure pathway, $i$ is the pollutant, $n_{E}[-]$ is the number of exposure pathways considered, $C A D D_{i}\left[\mathrm{M} \mathrm{M}^{-1} \mathrm{~T}^{-1}\right]$ is the chronic average daily dose and $R f D_{i}\left[\mathrm{M} \mathrm{M}^{-1} \mathrm{~T}^{-1}\right]$ is the corresponding (oral) reference dose.

The risk values $\left(H Q_{t o t, i} ; R L_{t o t, i}\right)$ are then summed over all the (known) compounds considered for a particular site in order to produce a risk (or hazard) index:

$R I=\sum_{i=1}^{n_{C}} R L_{t o t, i}$
$H I=\sum_{i=1}^{n_{C}} H Q_{t o t, i}$

where $R I[-]$ is the risk index, $n_{C}[-]$ is the number of compounds considered and $\mathrm{HI}[-]$ is the hazard index. Major assumptions include that exposure to any amount of a carcinogen will increase the cancer risk (i.e. no threshold dosage), risks are additive for multiple chemicals and (exposure) routes, and potential synergistic effects (between compounds) are not considered.

$L A D D_{i}$ and $C A D D_{i}$ result from exposure pathway functions (Strenge and Smith, 2006) that are based on a specific set of parameters (see Eq. (10)). These parameters are typically set to default values considered to be standard for a particular risk group (e.g. children) and toxicity assessment (e.g. carcinogens). The toxicity assessment is conducted using existing databases such as the Integrated Risk Information System (IRIS), maintained by the U.S. Environmental Protection Agency (U.S. EPA, 2009b), and the Risk Assessment Information System (RAIS) that is maintained by Oak Ridge National Laboratory for the U.S. Department of Energy (RAIS, 2009). The goal is to provide an estimate of the relationship between the magnitude of exposure and severity (noncarcinogens) or likelihood (carcinogens) of adverse effects. Thus, for carcinogens and for each exposure pathway, $L A D D_{i}$ can be determined by a set of equations following the U.S. EPA (1991, 2001, 2004) and ASTM (2004):

$$
\begin{aligned}
L A D D_{i, i n g} & =C_{i, w}\left[I R_{w} \frac{E F \times E D}{B W \times A T \times 365 \mathrm{~d} \mathrm{yr}^{-1}}\right] \\
L A D D_{i, i n h} & =C_{i, a}\left[I R_{a} \frac{E F \times E D}{B W \times A T \times 365 \mathrm{~d} \mathrm{yr}^{-1}}\right] K \\
L A D D_{i, d c} & =C_{i, w}\left[S A \times E T \frac{E F \times E D}{B W \times A T \times 365 \mathrm{~d} \mathrm{yr}^{-1}}\right] K_{p} \times C F_{1}
\end{aligned}
$$

where $L A D D_{i, \text { ing }}, L A D D_{i, \text { inh }}$ and $L A D D_{i, d c}$ are the average daily doses for the ingestion, inhalation and dermal contact pathways, respectively, $C_{i, w}\left[\mathrm{mg} \mathrm{L}^{-1}\right]$ and $C_{i, a}\left[\mathrm{mg} \mathrm{m}^{-3}\right]$ are the concentrations in water and air, respectively, $I R_{w}\left[\mathrm{Ld}^{-1}\right]$ is the water ingestion rate, $I R_{a}\left[\mathrm{~m}^{3} \mathrm{~d}^{-1}\right]$ is the air inhalation rate, $S A\left[\mathrm{~m}^{2}\right]$ is the exposed skin surface, $E T\left[\mathrm{hr} \mathrm{d}^{-1}\right]$ is the exposure time for an outdoor activity, $E F$ $\left[\mathrm{d} \mathrm{yr}^{-1}\right]$ is the frequency of exposure to the contaminant, ED [yr] is the exposure duration, $B W[\mathrm{~kg}]$ is the bodyweight, $A T[\mathrm{yr}]$ is the period over which the time is averaged, $K\left[\mathrm{~L} \mathrm{~m}^{-3}\right]$ is the Andelman volatilization factor for chemical pollutants, $K_{p}\left[\mathrm{~cm} \mathrm{hr}^{-1}\right]$ is the skin permeability coefficient for chemical $i$ and $C F_{1}\left[\mathrm{~L} \mathrm{~m} \mathrm{~cm}^{-1} \mathrm{~m}^{-3}\right]$ is a unit conversion factor.

\subsubsection{Ecological risk assessment}

This paper extends the CARO-PLUS model to assess the ecological impact of contaminants in surface water. An ecological risk assessment can be carried out in several ways. A rudimentary (i.e. conservative, screening level) method is to compare exposure point concentrations with ecotoxicity values for a set of ecological recep- 
Table 2

General (best estimate) parameter values used in the base case scenario, including aquifer, site and contamination parameters.

\begin{tabular}{|c|c|c|}
\hline & Estimate & Reference \\
\hline \multicolumn{3}{|l|}{ Aquifer parameters } \\
\hline Thickness [m] & 10 & GEO (2009) \\
\hline Hydraulic conductivity $\left[\mathrm{m} \mathrm{d}^{-1}\right]$ & 19 & Calibration parameter; Christensen and Raun (2005) \\
\hline Hydraulic gradient [-] & 0.00473 & Christensen and Raun (2005) \\
\hline Effective porosity [-] & 0.02 & GEO (2009) \\
\hline Seepage velocity $\left[\mathrm{m} \mathrm{d}^{-1}\right]$ & 4.5 & Calculated \\
\hline \multicolumn{3}{|l|}{ Site parameters } \\
\hline Aquifer material organic carbon content [-] & 0.002 & Christensen et al. (1996) \\
\hline Depth to GW $[\mathrm{m}]$ & 2 & GEO (2009) \\
\hline Longitudinal dispersivity [m] & 6.86 & Calculated; Xu and Eckstein (1995) \\
\hline Transverse vertical dispersivity [m] & 0.0001 & Klenk and Grathwohl (2002) \\
\hline Distance from source to P\&T well [m] & 500 & Christensen and Raun (2005) \\
\hline Distance from source to receptor [m] & 750 & Christensen and Raun (2005) \\
\hline Minimum (summer) surface water flux $\left[\mathrm{m}^{3} \mathrm{~d}^{-1}\right]$ & 544 & Bruun and Rose (2005) \\
\hline \multicolumn{3}{|l|}{ Contamination parameters } \\
\hline Pool width $[\mathrm{m}]$ & 11 & Calibration parameter \\
\hline Pool length [m] & 15 & Calibration parameter \\
\hline Thickness [m] & 10 & Calibration parameter \\
\hline NAPL molecular weight $\left[\mathrm{g} \mathrm{mol}^{-1}\right]$ & 131.4 & U.S. EPA (2009b) \\
\hline NAPL density $\left[\mathrm{kg} \mathrm{L}^{-1}\right]$ & 1.46 & U.S. EPA (2009b) \\
\hline Interfacial tension NAPL/water [dynes $\mathrm{cm}^{-1}$ ] & 42 & Mayer and Hassanizadeh (2005) \\
\hline Interfacial tension NAPL/air [dynes $\mathrm{cm}^{-1}$ ] & 32 & Mayer and Hassanizadeh (2005) \\
\hline
\end{tabular}

tors using (U.S. EPA, 1997a):

$H Q_{i}=\frac{E E C_{i}}{N O A E C_{i}}$

where $H Q_{i}[-]$ is the hazard quotient for pollutant $i, E E C_{i}\left[\mathrm{M} \mathrm{L}^{3}\right]$ is the estimated concentration at the exposure point and $N O A E C_{i}\left[\mathrm{M} \mathrm{L}^{3}\right]$ is the no-observed-adverse-effects-concentration. The $N O A E C_{i}$ values were taken from the online database ECOTOX maintained by the U.S. EPA (2009a). The U.S. EPA advises that these conservative results can be used to determine whether ecological threats are negligible or whether a more detailed ecological risk assessment is required.

The simple ecological assessment approach described above has been criticized since $N O A E C_{i}$ reference values exist only for a few ecological receptors and a high uncertainty exists for the extrapolation of these values to other organisms (Tannenbaum, 2005). A more comprehensive ecological risk assessment can be made using the freshwater ecosystem simulation model AQUATOX. AQUATOX combines the simulation of an aquatic ecosystem with the environmental fate and effect of various pollutants, such as nutrients and organic chemicals. The model is capable of computing endpoint concentrations for pollutants in both water and bottom sediments, as well as their effects on a variety of aquatic flora and fauna. A detailed description of AQUATOX including the specific calculations for ecosystem health parameters is included in Park and Clough (2004), Park et al. (2008) and references therein.

\subsection{Uncertainty assessment}

One of the goals of this paper is to carry out a quantitative exposure assessment, including an in-depth investigation into how uncertainty influences management decisions. By segregating the uncertainties that are specific for the exposure parameters in a particular land use scenario from those that are site- and contaminant-specific, the investigator can work to reduce the uncertainties associated with the site, while being able to recognize the uncertainties inherent in the exposure process. This process leads to robust management strategies.

Uncertainty was investigated using Monte-Carlo simulation of the site-specific parameters within CARO-PLUS. A Latin hypercube method was used to sample parameter values from given distributions. After generation of the Monte-Carlo output, the simulation results were post-processed to remove model outcomes that lie outside a predefined acceptable range. This "model screening" is a necessary measure since parameter values inherent to the MonteCarlo process are drawn randomly from their individual probability distributions, and can therefore be combined in ways that are physically infeasible and their consideration would decrease the validity of the results.

\section{Results: application to Skensved stream}

\subsection{Source characterization and groundwater transport model}

The CARO-PLUS model was utilized to simulate the TCE flux from the source area to the hyporheic zone as a function of time. Table 2 presents a summary of the general parameter values implemented in the base case scenario. Hydraulic conductivity was used as a calibration parameter for (model) transport, based on the range given in Christensen and Raun (2005). All further transport parameters could be taken either from site-specific investigations or the literature.

The historical conditions in the source zone are not known, and so observed concentrations measured down-gradient of the source zone for two different points in time (1995 - pre-pump and treat - and 2005) are used to calibrate the source zone geometry in the model (see results in Table 2). Measurement information for calibration of the transport model is taken from remediation well B11 (500 $\mathrm{m}$ down-gradient, Fig. 1) and well 3B located in the hyporheic zone ( $750 \mathrm{~m}$ down-gradient, Figs. 1 and 2 ). The model calibration assumes that TCE degradation is not occurring at this site, due to the prevailing redox conditions and absence of degradation products.

Calibration of the model results in an initial volume and mass of TCE of $33 \mathrm{~m}^{3}$ and 48.2 tons, respectively. The calibrated model fits well to concentrations measured in 1995 of $280 \mu \mathrm{g} \mathrm{L}^{-1}$ at well B11 (compared with $309 \mu \mathrm{g} \mathrm{L}^{-1}$ modeled - data not shown) and $160 \mu \mathrm{g} \mathrm{L}^{-1}$ in well 3B (compared with $174 \mu \mathrm{g} \mathrm{L}^{-1}$ modeled, Fig. 5B). A concentration of $120 \mu \mathrm{g} \mathrm{L}^{-1}$ was measured in well 3B in 2005 (see Fig. 2), again comparing well with the modeled value of $129 \mu \mathrm{g} \mathrm{L}^{-1}$ (Fig. 5B). 

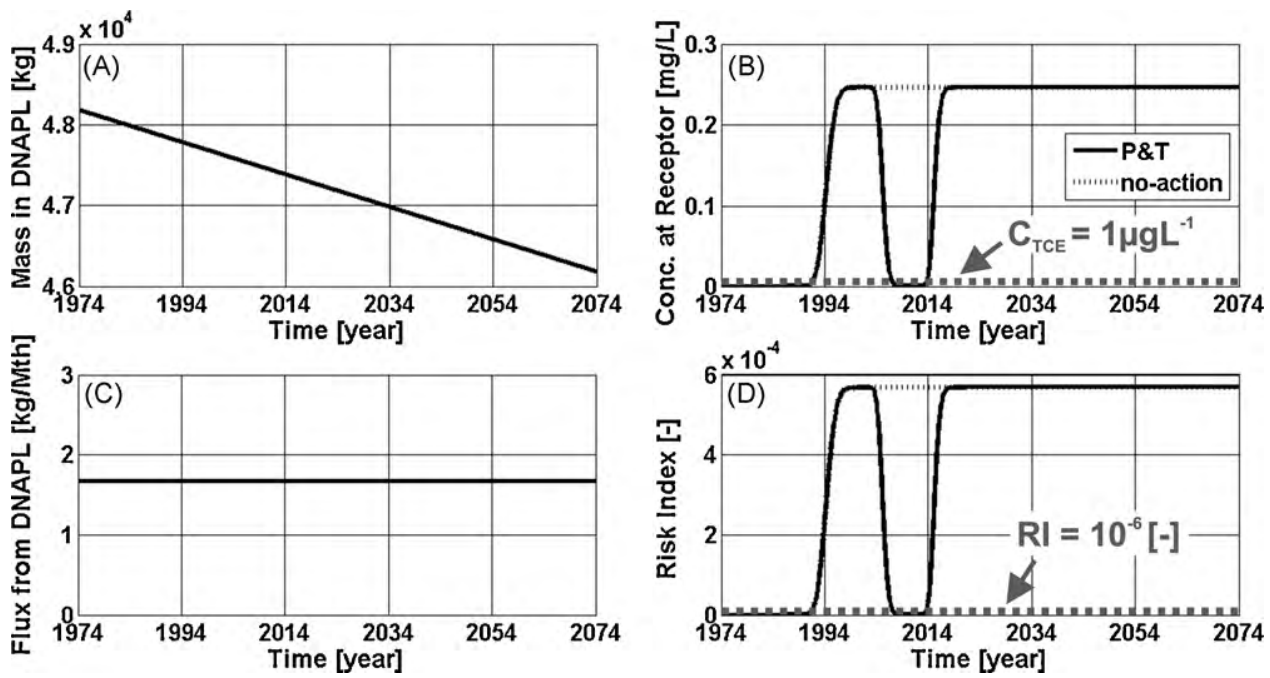

Fig. 5. Output of the source zone and groundwater models: (A) mass depletion, (B) concentration at stream receptor (750 m), (C) aqueous mass flux from DNAPL source zone and (D) risk index. Also shown, as a dashed horizontal line, are the management targets associated with (B) TCE concentration and (D) risk index.

\subsection{Human health risk assessment based on groundwater concentrations}

The results from the groundwater transport model can be used for an initial calculation of risk to human health. The cancer classification for TCE is still under review by the U.S. EPA (2009b). However, it is currently classified as a possible-probable carcinogen by the Agency for Toxic Substances and Disease Registry (ATSDR, 1997), and is listed as "medium priority" by the International Agency for Research on Cancer (IARC, 2008). Thus, it makes sense to conduct the risk assessment for the case that TCE can be classified as carcinogenic. In addition, the most sensitive target risk group is chosen - children. Table 3 lists the exposure pathways determined to be potentially relevant for this receptor. It should be noted that CARO-PLUS considers receptor endpoints such as surface water (i.e. fin fish ingestion, shoreline sediment ingestion) from a risk perspective. Contaminant concentrations in surface water are calculated by a simple dilution model, i.e. through mixing of the contaminated groundwater with surface water. The risk scenario was conducted for the worst-case, i.e. fish are assumed to ingest a mixture of groundwater and stream water where the amounts were determined by the groundwater flow rate and the low (summer) observed surface water flux.

Table 3 shows the results of the risk assessment: the exposure pathways considered and their associated maximum (calculated) risk index. The maximum concentration was calculated to be $247 \mu \mathrm{g} \mathrm{L}^{-1}$ in groundwater used for drinking (first occurring in July 2021) and the risk index was determined to be $5.68 \times 10^{-4}$ (October 2021). These can be compared with target risk levels

Table 3

Summary of the human health assessment including initial set of exposure pathways and their corresponding maximum $R I_{i, k}$.

\begin{tabular}{ll}
\hline Exposure pathways & Maximum $R I_{i, k}[-]$ \\
\hline Drinking water ingestion & $\mathbf{5 . 6 5 E}-\mathbf{0 4}$ \\
Fin fish ingestion & $\mathbf{2 . 2 3 E}-\mathbf{0 6}$ \\
Shoreline sediment ingestion & $3.63 \mathrm{E}-11$ \\
Soil ingestion & $3.75 \mathrm{E}-08$ \\
Inhalation of re-suspended soil & $2.71 \mathrm{E}-10$ \\
Outdoor air inhalation & $1.68 \mathrm{E}-07$ \\
Soil dermal contact & $6.25 \mathrm{E}-08$ \\
Shoreline sediment dermal contact & $1.21 \mathrm{E}-10$ \\
Maximum $R I_{i}[-]$ & $5.68 \mathrm{E}-04$ \\
\hline
\end{tabular}

of $10^{-6}$ and maximum allowable TCE concentrations of $10 \mu \mathrm{g} \mathrm{L}^{-1}$ and $1 \mu \mathrm{g} \mathrm{L}^{-1}$ in surface and groundwater, respectively (Miljø-og Energiministeriet, 1996; Miljøstyrelsen, 1998).

Of the eight pathways considered for the receptor, only two pathways play a significant role in causing risk to the receptor (marked in bold in Table 3). The drinking water ingestion pathway assumes that groundwater is used directly for drinking water (e.g. from a private well) without treatment. The sum of the risk indices for the six least important pathways is $2.69 \times 10^{-7}$, thereby meeting the risk management target of $10^{-6}$.

Fig. 5 shows overall results of the risk assessment based on groundwater concentrations, including (A) mass depletion, (B) aqueous mass flux from NAPL source zone, (C) concentration at the receptor $(750 \mathrm{~m})$ and $(\mathrm{D})$ risk index for a simulation period of 100 years. The figure shows the impact of the pump and treat (P\&T) system used for source control and the outcome if pump and treat had not been employed. The effect of the pump and treat containment strategy can be seen in the decreasing concentrations and risk between 1999 and 2009. The model shows that if the current pump and treat system is switched off in 2009, then the concentration and risk will rebound in 2014. This means that when the pump and treat action is terminated, both management targets of $1 \mu \mathrm{g} \mathrm{L}^{-1}$ in groundwater (Fig. 5B) and $R I=10^{-6}$ (Fig. 5D) will be exceeded in the base case scenario.

\subsection{Surface water transport model}

The parameter values utilized in the analytical volatilization model are summarized in Table 4. Several of the parameters in the model are known to be nonstationary (e.g. surface water flow, cross-sectional area), in part due to seasonal changes. To evaluate the worst-case, the model was set up to simulate the conditions during the summer, which is characterized by low water fluxes and water levels.

Using the volatilization and groundwater inflow rates as fitting parameters, the volatilization model was fitted to the measured TCE concentrations, as shown in Fig. 6. Three separate groundwater inflow sections were identified, with the first occurring at $1625 \mathrm{~m}$ and approximately $250 \mathrm{~m}$ long, the second only $75 \mathrm{~m} \mathrm{long}$, and the third encompassing the remainder of the investigated stream section. The initial values for the first two groundwater inflow rates were taken from the measured data (e.g. $336 \mathrm{~L} \mathrm{~m}^{-2} \mathrm{~d}^{-1}$ at $1674 \mathrm{~m}$ 
Table 4

Input parameters for the volatilization model.

\begin{tabular}{lcl}
\hline Parameter & Value & Reference \\
\hline TCE concentration in groundwater $\left[\mu \mathrm{g} \mathrm{L}^{-1}\right]$ & 130 & CARO-PLUS output \\
Stream depth $[\mathrm{m}]$ & 0.11 & Minimum value; Bruun and Rose (2005) \\
Stream width $[\mathrm{m}]$ & 1.4 & Average value; Bruun and Rose (2005) \\
Surface water flux $\left[\mathrm{m} \mathrm{d}^{-1}\right]$ & 3366 & Bruun and Rose (2005) \\
Volatilization rate $\left[\mathrm{d}^{-1}\right]$ & 19 & Fitting parameter \\
Groundwater inflow rate I $\left[\mathrm{L} \mathrm{m}^{-2} \mathrm{~d}^{-1}\right]$ & 360 & Fitting parameter \\
Groundwater inflow rate II $\left[\mathrm{L} \mathrm{m}^{-2} \mathrm{~d}^{-1}\right]$ & 30 & Fitting parameter \\
Groundwater inflow rate III $\left[\mathrm{L} \mathrm{m}^{-2} \mathrm{~d}^{-1}\right]$ & 18 & Fitting parameter \\
\hline
\end{tabular}

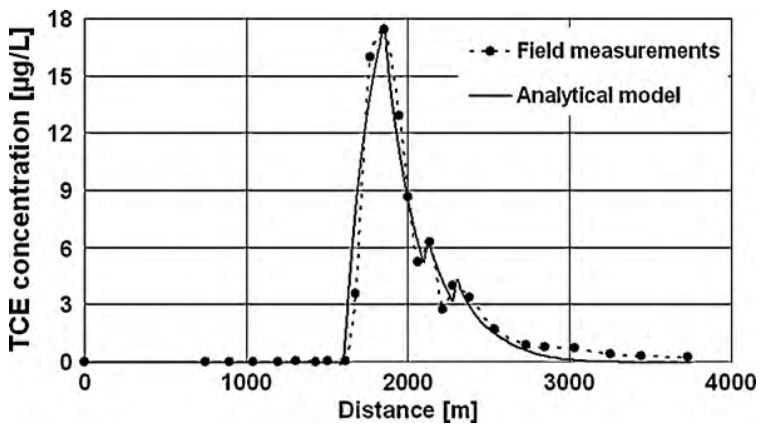

Fig. 6. Analytical volatilization model (solid line) fitted to actual TCE concentrations (dashed line) measured in August 2005, by accounting for both volatilization and upstream inflows. The two "jumps" were fitted by including downstream groundwater-to-surface water influx areas.

and $84 \mathrm{~L} \mathrm{~m}^{-2} \mathrm{~d}^{-1}$ at $1765 \mathrm{~m}$ ) and then adjusted. No initial data were available for the third rate. The figure shows two "jumps" in the TCE concentration at $2125 \mathrm{~m}$ and $2300 \mathrm{~m}$ and these can be explained by the model if it includes the increased groundwater infiltration rates at these points (see Fig. 6).

The model can be used to determine the stream reach over which the surface water quality criteria for TCE has been exceeded, namely between $1700 \mathrm{~m}$ and $2000 \mathrm{~m}$ (Fig. 6). That is, only $300 \mathrm{~m}$ of the Skensved stream is actually affected by the TCE contamination (i.e. fails to meet surface water quality criteria) from the contaminated groundwater.

\subsection{Human health risk assessment based on surface water concentrations}

The maximum modeled (and observed) TCE concentration in the surface water of $17.4 \mu \mathrm{g} \mathrm{L}^{-1}$ was used to assess the human health risk for children. This second human health risk assessment was conducted specifically for the potential exposure scenario of children playing outdoors in the contaminated stretch of Skensved stream. For a recreational land use scenario, risk from surface water is the sum of ingestion, inhalation and dermal contact with the water.

Isolating $L A D D_{i}$ in Eq. (8) and then solving for the respective contaminant concentrations from Eq. (10) allows the determination of the maximum allowable concentrations in water and air for a specific risk target, e.g. $R I=10^{-6}$. Using the parameter values listed in Table 5, the maximum allowable concentrations in water for the ingestion and dermal contact pathways were found to be $54.2 \mu \mathrm{g} \mathrm{L}^{-1}$ and $25.4 \mu \mathrm{g} \mathrm{L}^{-1}$, respectively. Both of these values are above the TCE concentration actually measured in the stream. Similarly, the maximum allowable concentration in air for the inhalation pathway was found to be $0.7 \mu \mathrm{g} \mathrm{L}^{-1}$. No data exist for TCE concentrations in the air in this vicinity for comparison purposes.

\subsection{Preliminary ecological risk assessment in the stream}

Indicator organisms were selected for the screening-level ecological risk assessment (e.g. according to Eq. (11)), including Daphnia magna (aquatic crustaceans), mayfly and minnow (representing fin fish). TCE toxicity data can be found for these three organisms in the U.S. EPA ECOTOX database (U.S. EPA, 2009a). The respective hazard quotients were calculated to be $0.013,0.0004$ and 0.001 , respectively, and all were well below the target value of 1 . Neither $D$. magna nor minnow are typically found in small Danish streams (Dall and Lindegaard, 1995). However, D. magna and minnow were chosen to represent Gammarus pulex (common freshwater shrimp) and (juvenile) Salmo trutta (brown trout), both of which are common inhabitants of small Danish streams (Dall and Lindegaard, 1995). Furthermore, species of the mayfly family, Baetidae, are frequently found in Danish streams. The chosen indicator organisms are thus assumed to represent different trophic levels in a simplified Danish stream ecosystem. NOAECs for $D$. magna and G. pulex are comparably low in terms of other toxicant

Table 5

Parameter values used in the assessment of human health (i.e. children) exposure to contaminated surface water.

\begin{tabular}{|c|c|c|}
\hline Parameter & Value & Notes/references \\
\hline Exposure frequency, $E F\left[\mathrm{~d} \mathrm{yr}^{-1}\right]$ & 90 & Best estimate, recreational scenario \\
\hline Exposure time for outdoor activity, $E T\left[\mathrm{hr} \mathrm{d}^{-1}\right]$ & 0.75 & Best estimate, recreational scenario \\
\hline Surface water ingestion rate, $I R_{w}\left[\mathrm{Ld}^{-1}\right]$ & 0.05 & U.S. EPA (1997b) \\
\hline Inhalation rate, $I R_{a}\left[\mathrm{~m}^{3} \mathrm{~d}^{-1}\right]$ & 7.5 & ECETOC (2001) \\
\hline Body weight, $B W[\mathrm{~kg}]$ & 21.4 & ECETOC (2001) \\
\hline Averaging time, $A T[\mathrm{yr}]$ & 75 & ECETOC (2001) \\
\hline Unit conversion factor, $C F_{1}\left[\mathrm{~L} \mathrm{~m} \mathrm{~cm}^{-1} \mathrm{~m}^{-3}\right]$ & 10 & Default; U.S. EPA (1991) \\
\hline Andelman volatilization factor, $K\left[\mathrm{~L} \mathrm{~m}^{-3}\right]$ & 0.5 & Default; U.S. EPA (1991) \\
\hline Exposure duration, $E D$ [yr] & 6 & Default; U.S. EPA (1991) \\
\hline Exposed skin surface area, $S A\left[\mathrm{~m}^{2}\right]$ & 0.9052 & Calculated as $423 \mathrm{~cm}^{2} / \mathrm{kg}$; ECETOC (2001) \\
\hline Skin permeability coefficient, $K_{p}\left[\mathrm{~cm} \mathrm{hr}^{-1}\right]$ & 0.0157 & Chemical-specific; RAIS (2009) \\
\hline Fraction of contaminant absorbed in the gastrointestinal tract, $G I[-]$ & 1.0 & Chemical-specific; RAIS (2009) \\
\hline Oral slope factor for ingestion pathway, $S F_{o}\left[\mathrm{~kg} \mathrm{~d} \mathrm{mg}^{-1}\right]$ & 0.4 & Chemical-specific; RAIS (2009) \\
\hline Oral slope factor for inhalation pathway, $S F_{i}\left[\mathrm{~kg} \mathrm{~d} \mathrm{mg}^{-1}\right]$ & 0.4 & Chemical-specific; RAIS (2009) \\
\hline Oral slope factor for dermal contact pathway, $S F_{d}\left[\mathrm{~kg} \mathrm{~d} \mathrm{mg}^{-1}\right]$ & 0.4 & Chemical-specific; calculated as $S F_{o} / G I$ (U.S. EPA, 2004) \\
\hline
\end{tabular}


Table 6

Parameter values used in AQUATOX for the assessment of ecological health.

\begin{tabular}{|c|c|c|c|c|c|}
\hline Animal toxicity data & Initial conditions [ $\left.\mathrm{g} \mathrm{m}^{-2} \mathrm{dry}\right]$ & $\mathrm{LC}_{50}\left[\mu \mathrm{g} \mathrm{L}^{-1}\right]$ & $\mathrm{LC}_{50}$ experimental time $[\mathrm{h}]$ & Lipid fraction [-] & Average wet weight [\%] \\
\hline Stonefly & $0.5^{\mathrm{a}}$ & $70,000^{\mathrm{b}}$ & $48^{\mathrm{b}}$ & $0.05^{\mathrm{a}}$ & $0.03^{\mathrm{a}}$ \\
\hline Oligochaete & $1^{\mathrm{a}}$ & $132,000^{\mathrm{b}}$ & $48^{\mathrm{b}}$ & $0^{\mathrm{a}}$ & $0^{\mathrm{a}}$ \\
\hline Minnow & $2^{\mathrm{a}}$ & $52,000^{c}$ & $24^{\mathrm{c}}$ & $0.047^{\mathrm{a}}$ & $2^{\mathrm{a}}$ \\
\hline Ostracod & $0.65^{\mathrm{a}}$ & $56,000^{\mathrm{b}}$ & $48^{\mathrm{b}}$ & $0.05^{\mathrm{a}}$ & $0.002^{\mathrm{a}}$ \\
\hline Chironomid & $0.5^{\mathrm{a}}$ & $42,000^{b}$ & $48^{\mathrm{b}}$ & $0.06^{\mathrm{a}}$ & $0.0006^{\mathrm{a}}$ \\
\hline D. magna & $0.03^{\mathrm{a}}$ & $22,000^{\mathrm{a}}$ & $24^{\mathrm{a}}$ & $0.06^{\mathrm{a}}$ & $0.0006^{\mathrm{a}}$ \\
\hline Plant toxicity data & Initial conditions [ $\mathrm{g} \mathrm{m}^{-2}$ dry] & \multicolumn{2}{|c|}{$\mathrm{EC}_{50}$ photo $\left[\mu \mathrm{g} \mathrm{L}^{-1}\right]$} & $\mathrm{EC}_{50}$ experimental time [h] & Lipid fraction [-] \\
\hline Macrophytes & $2^{\mathrm{a}}$ & \multicolumn{2}{|c|}{0} & 0 & $0.02^{\mathrm{a}}$ \\
\hline Bluegreens & $1.2^{\mathrm{a}}$ & \multicolumn{2}{|c|}{$63,000^{\mathrm{a}}$} & $192^{\mathrm{a}}$ & $0.05^{\mathrm{a}}$ \\
\hline Greens & $0.05^{\mathrm{a}}$ & \multicolumn{2}{|c|}{$390,000^{c}$} & $96^{c}$ & $0.05^{\mathrm{a}}$ \\
\hline Diatoms & $1.2^{\mathrm{a}}$ & $150,000^{\mathrm{a}}$ & & $96^{\mathrm{a}}$ & $0.05^{\mathrm{a}}$ \\
\hline
\end{tabular}

a U.S. EPA (2009a).

b Kegley et al. (2008).

c Rippen (1995).

groups (e.g. pesticides, Møhlenberg et al., 2004), and we therefore assume that $D$. magna here is representative of $G$. pulex as the most sensitive organism at the TCE polluted stretch in Skensved stream.

\subsection{Comprehensive ecological risk assessment in the stream}

In order to conduct a more comprehensive ecological risk assessment, the AQUATOX model was set up to model the $300 \mathrm{~m}$ stretch of the Skensved stream impacted by the TCE groundwater plume. Although the Skensved site was extensively characterized, much of the data needed for input to AQUATOX were not available (e.g. lipid fraction for the various organisms modeled). Instead, unknown parameters were based on an existing case study in AQUATOX, where the impact of an organic toxicant is simulated and verified for a generic Ohio creek (see Table 6 for parameters). Biomasses of the included autotrophic components were maintained at low levels because of the small stream size and expected high level of human maintenance activities. Shading effects of stream bank vegetation increase proportionately with decreasing stream size (Allan, 1995). Furthermore, the vast majority of small Danish streams have lowered stream beds due to heavy and frequent maintenance which, additionally, increase shading effects of bank vegetation. We therefore propose that primary production is low at this impacted stretch of Skensved stream. Please note that some of the ecotoxicological parameters could be either estimated directly from the parameters given in Table 6 (e.g. animal/plant $\mathrm{K} 2$ elimination rate constants), or were estimated as suggested within the existing case study (e.g. animal $\mathrm{EC}_{50}$ growth/reproduction values were estimated using the $D$. magna $\mathrm{LC}_{50} / \mathrm{EC}_{50}$ ratio; see U.S. EPA, 2009c for more details). The "Mannings Equation" method was selected for computing the water body volume in AQUATOX, based on existing (dynamic) outflow data for 2008.

Fig. 7A shows the observed stream discharge and modeled TCE concentration for 1 year. In July, the water volume reaches its annual minimum of $20 \mathrm{~m}^{3}$ (over $300 \mathrm{~m}$, corresponding to $0.8 \mathrm{~m}^{3}$ per $\mathrm{m}$ stream), and the TCE concentration peaks at just over $16 \mu \mathrm{g} \mathrm{L}^{-1}$. In general, the pattern of peaks seen on both curves shows that a clear correlation exists between the water volume and the TCE concentration, with high water volumes reflecting low TCE concentrations.

Fig. 7B illustrates the modeling results for the calculated bioaccumulation factor for four species (D. magna, stonefly, mayfly and minnow) versus TCE concentration. A trend clearly exists, with an increasing bioaccumulation factor from the lowest to the highest trophic level (i.e. moving from $D$. magna to minnow and bottom to top in Fig. 7B). It can also be seen that the bioaccumulation factor

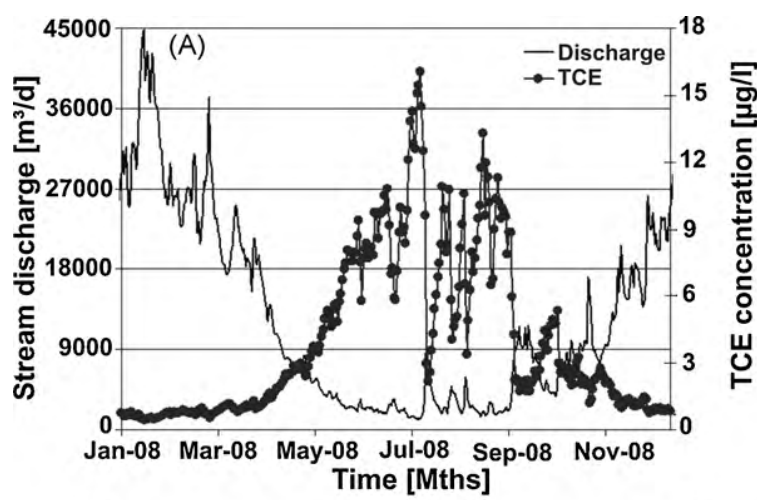

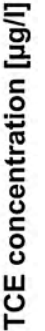
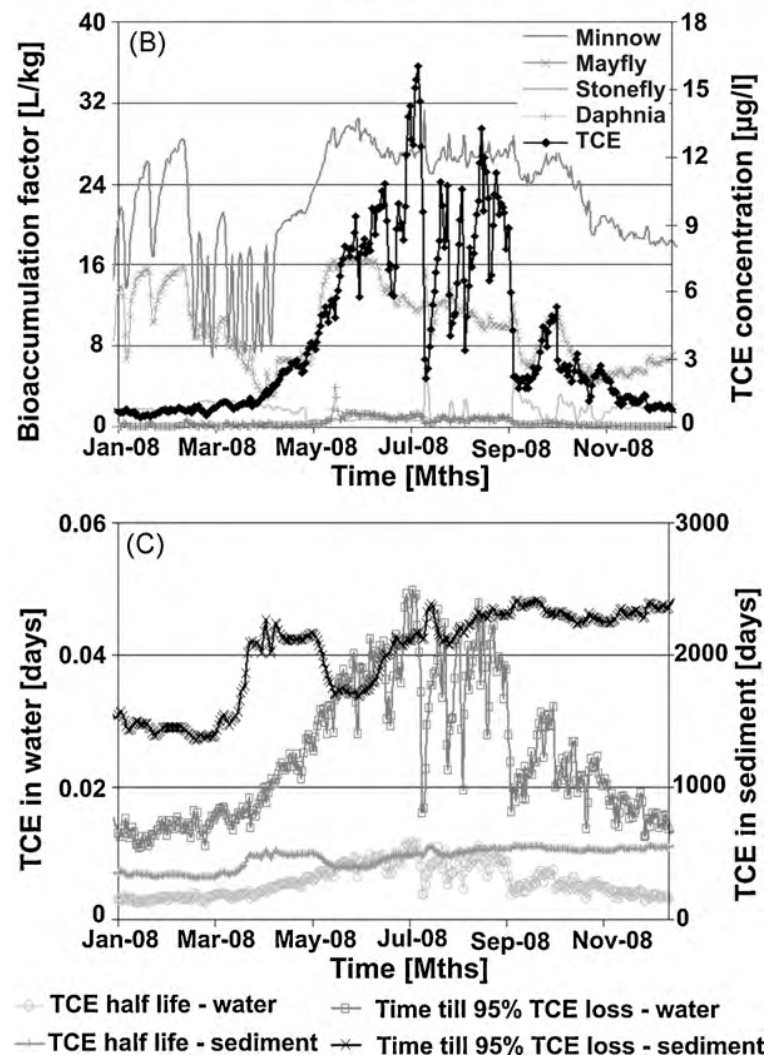

Fig. 7. AQUATOX results for (A) stream discharge and (B) bioaccumulation factor versus TCE concentration for the $300 \mathrm{~m}$ groundwater-impacted stream stretch, and (C) half-lives for both TCE in water and sediment, as well as time required for $95 \%$ TCE loss in both water and sediment. 

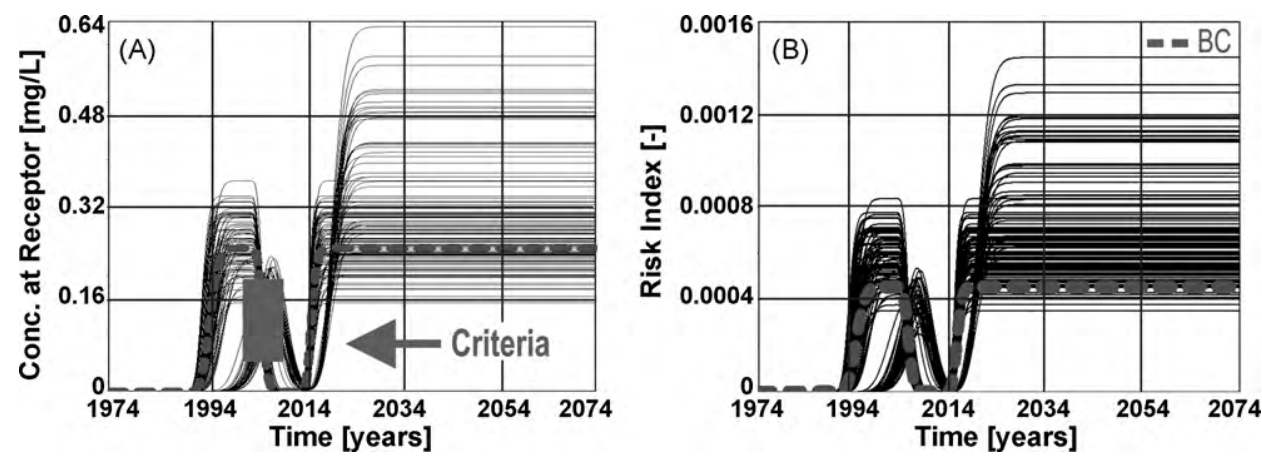

Fig. 8. Monte-Carlo realizations of the transport and risk assessment model for (A) concentration at receptor and (B) risk index over time. Note that the base case (BC) model run is indicated in both figures as a dashed line. The model screening criteria (predicted concentrations at receptor $=$ observed concentration at receptor $\pm 50 \%$ ) is indicated in (A) by the range allowed (vertical bar) in 2005.

Table 7

Site-specific parameters varied in the Monte-Carlo sensitivity test.

\begin{tabular}{lllll}
\hline (Input) Parameter & Estimate & Min & Max & Peak \\
\hline Hydraulic conductivity [ $\mathrm{m} \mathrm{d}^{-1}$ ] & 19 & 9.5 & 28.5 & - \\
Transverse vertical dispersivity [m] & 0.0001 & 0.00004 & 0.00015 & - \\
DNAPL pool length [m] & 15 & 10 & 30 & 15 \\
\hline
\end{tabular}

increases with TCE concentration in the summer months (i.e. from May to September).

D. magna was found by AQUATOX to be the most sensitive species modeled (data not shown). However, a close comparison of the $D$. magna concentration between the perturbed and control (no TCE present) scenarios indicates that there were no ecosystem effects occurring. This low ecosystem impact is expected as the NOAEC

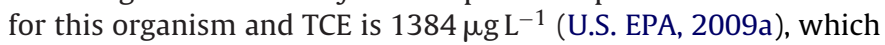
is much higher than the observed surface water concentration of $17.4 \mu \mathrm{g} \mathrm{L}^{-1}$.

The half-life of a contaminant provides a good indication of the length of time in which a stream will be impacted by the contaminant. Fig. 7C depicts the modeled TCE half-life in water and sediment (bottom two curves) and the time for 95\% chemical loss (upper two curves). Both parameters in water (versus sediment) follow the trend for TCE concentration (depicted in Fig. 7B). In contrast, both half-life and time for 95\% chemical loss in sediment are less affected by the dynamically changing TCE concentration. Simulations were carried out for 5 years (2008-2012), and it was observed that the trends evident in Fig. 7 simply repeat themselves, producing a yearly cycling pattern (data not shown).

\subsection{Uncertainty assessment}

Monte-Carlo simulation was used to assess the uncertainty of the results from the groundwater transport model, focusing on the role of the highly uncertain or effective parameters on the decision process. Table 7 lists the parameters and ranges applied for the analysis. Input parameters were described using either triangular or uniform distributions, where the degree of variation (i.e. spread) reflected the estimated uncertainty for a specific parameter (e.g. van Groenendaal and Kleijnen, 2002).

Simulations were done for an ensemble of 500 realizations. The outcome was then screened in order to generate a subset of realizations that are consistent with actual site data. A subset of 112 realizations was produced utilizing a screening criterion that requires the predicted (model) concentrations to be within $\pm 50 \%$ of the observed concentration measured at the receptor in 2005.

Uncertainties in input data (Table 7) lead to uncertainties in model output. The simulation results show that TCE concentration and resulting risk to the receptor may be approximately three times higher or two times lower than was predicted for the base case (Fig. 8). Interestingly, two "trends" or sets of curves can be distinguished in Fig. 8. A deterministic sensitivity analysis using the allowable, i.e. screened parameter ranges showed that lower values of hydraulic conductivity were responsible for the set of curves appearing with a later breakthrough time, i.e. in 2000. Both transverse vertical dispersivity and DNAPL pool length had no observable effect on the time for the first breakthrough, but were instead responsible for the resulting "spread" of both maximum concentration and risk indices. This also plays a role in model predictions in which contaminant concentrations can be expected to decrease as a result of the pump and treat strategy.

A synopsis of the results of the Monte-Carlo simulation is provided in Table 8. Ranges of input parameters are narrow compared with the previously defined ranges (see Table 7) as a consequence of model screening. The coefficient of variation $(\mathrm{CV})$ may be used to quantify how the original uncertainties have "propagated" through the modeling system. The probability distributions of input and output parameters appear to be very similar.

The results of the sensitivity analysis for the output variables were also analyzed for the October 2021 (indicated as $t=10-2021$ in Fig. 9) time step corresponding to the time of maximum risk value, using histograms. For both concentration at receptor and risk index, the base case values fell into the ranges containing the

Table 8

Summary statistics for the Monte-Carlo simulations for selected input and output parameters (at $t=10-2021$ ).

\begin{tabular}{|c|c|c|c|c|c|c|}
\hline Parameter & Min & Max & Median & Mean & StDev & $\mathrm{CV}$ \\
\hline \multicolumn{7}{|l|}{ Input parameters } \\
\hline Hydraulic conductivity [ $\left.\mathrm{m} \mathrm{d}^{-1}\right]$ & 10.96 & 20.69 & 18.26 & 16.64 & 3.46 & 0.21 \\
\hline Transverse vertical dispersivity [m] & $4.0 \mathrm{E}-05$ & $1.5 \mathrm{E}-04$ & $9.0 \mathrm{E}-05$ & $9.3 \mathrm{E}-05$ & $3.2 \mathrm{E}-05$ & 0.35 \\
\hline DNAPL pool length [m] & 10.95 & 29.41 & 17.04 & 17.89 & 4.43 & 0.25 \\
\hline \multicolumn{7}{|l|}{ Output parameters } \\
\hline Concentration at receptor $\left[\mathrm{mg} \mathrm{L}^{-1}\right]$ & 0.153 & 0.489 & 0.273 & 0.279 & 0.065 & 0.23 \\
\hline$R I[-]$ & $3.52 \mathrm{E}-04$ & $1.12 \mathrm{E}-03$ & $6.26 \mathrm{E}-04$ & $6.41 \mathrm{E}-04$ & $1.49 \mathrm{E}-04$ & 0.23 \\
\hline
\end{tabular}



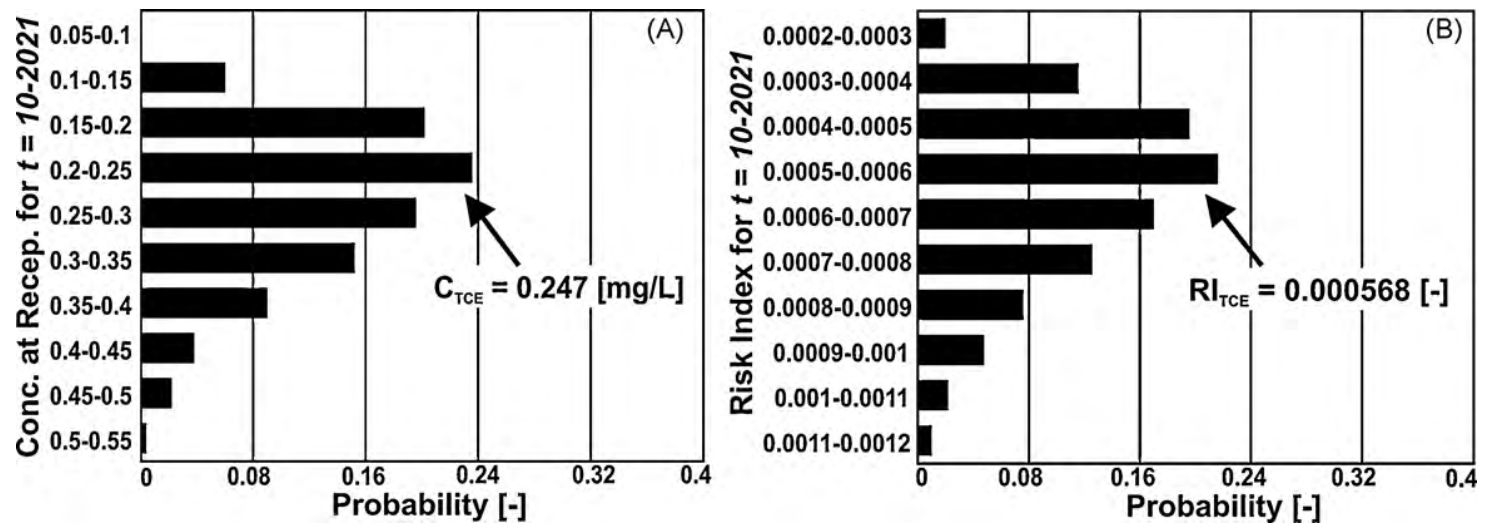

Fig. 9. Histograms showing the probability distribution for (A) TCE concentration at receptor and (B) risk index at the expected time of maximum risk ( $t=10-2021)$. The specific subset range containing the base case modeled value is indicated by arrows.

largest probability with predicted probabilities of $24 \%$ and $22 \%$, respectively.

\section{Conclusions}

This paper has shown how integrated modeling can support both human health and ecological risk assessments for surface waters potentially impacted by point sources in groundwater. The decision support system CARO-PLUS allows for a model-based, multi-compartmental environmental impact assessment designed to establish the suitability of management scenarios capable of meeting predefined, site-specific compliance criteria. It is based on a quantitative exposure assessment and determination of risks for potential receptors deemed relevant for a particular site. This approach is intended to evaluate and reduce the number of competitive options for any further detailed assessment.

The results of the screening tool at the Skensved site indicate an unsettling trend, with TCE concentrations (in groundwater) reaching a maximum of $250 \mu \mathrm{g} \mathrm{L}^{-1}$ that will hold steady for many decades to come. The plume today is under hydraulic control, but the results suggest that pump and treat, functioning either as a remediation or as a containment strategy, may not be a sustainable management solution for this site.

For the human health risk assessment in surface water, no (carcinogenic) risk was found for the developed worst-case scenario, i.e. children, in a recreational setting. Measured and modeled TCE concentrations in surface water were found to be below the estimated maximum allowable concentrations in water for meeting the risk management target of $10^{-6}$. These results are dependent on the actual values chosen for the scenario. Risk was only found to exist if the groundwater was to be used as drinking water, with maximum modeled concentration and risk values of $247 \mu \mathrm{g} \mathrm{L}^{-1}$ and $5.68 \times 10^{-4}$, respectively.

The results of the volatilization model could be used to determine the stream reach over which surface water quality criteria have been exceeded. This corresponded to the $300 \mathrm{~m}$ stretch where the TCE plume actually infiltrates the Skensved stream. TCE concentrations, as well as water levels were used for a preliminary verification to support the quantitative ecological risk assessment. The applied ecosystem model AQUATOX was found to capture these trends well, when compared with actual data. Two major drawbacks, however, were found to exist when using the AQUATOX model for preliminary assessment: the extremely large number of parameters needed to create a functioning ecosystem, and the fact that specific organisms not currently included in the model cannot be added by the user.
For the ecological risk assessment, it was found that the TCE contamination does not have any significant effect on the stream ecosystem. These results indicate that volatile organic solvents may not pose a threat to surface water ecosystems. Caution is warranted however, since the only chemical investigated was TCE and ecosystem effects were modeled based on the impact of TCE on three indicator organisms assumed to represent common species in small Danish streams. This is also reflected in the high NOAEC values found for all organisms investigated. Further modeling studies are needed, including studies comparing ecosystem impacts for both chronic and acute toxicants. We additionally propose that conducting subsequent supplementary field studies is highly necessary to improve the evaluation of modeling results, when ecosystem modeling input is restricted to only a few species which potentially are not present at the site in question.

Uncertainty with respect to transport modeling parameters was also investigated. The hydraulic conductivity was found to be the most critical site-specific parameter, suggesting that additional effort should be directed towards it when prioritizing future investigation needs. Sensitivity analyses confirmed that an evaluation of uncertainties for site-specific parameters is critical to sound decision-making and must be taken into consideration in any quantitative assessment

The implementation of system dynamics to hydrogeological issues recognizes the increasing importance of interdisciplinary systems research that relates policy assessment to resource management options. The risk assessment tools developed in this paper serve to integrate multiple issues, interest groups, disciplines and scales in order to address the wide-ranging impacts of controllable and uncontrollable socioeconomic, ecological, hydrological and institutional drivers.

\section{Acknowledgements}

The authors gratefully acknowledge the support of the German BMBF research priority program KORA (contract no. 02WN0382 and 02WN0300), the Helmholtz Centre for Environmental Research in Leipzig (contract no. UFZ-01/2007) and the Danish Research Council (grant no. 2104-07-0035). Travel grants to the HydroEco2009 conference in Vienna, Austria, were provided by the Technical University of Denmark. The field data reported in this paper are the results of several studies conducted at the Technical University of Denmark by Stine Brok Christensen, Kristian Dragsbaek Raun, Simon Bruun, Jonas Rose, Anna Juliane Clausen, Mette Fjendbo Petersen, Eva Mathilde Riis Hedegaard, and supported by their advisors Poul L. Bjerg, Peter Bauer-Gottwein and Anders Baun. 


\section{References}

Abe, Y., Aravena, R., Zopfi, J., Parker, B., Hunkeler, D., 2009. Evaluating the fate of chlorinated ethenes in streambed sediments by combining stable isotope, geochemical and microbial methods. J. Contam. Hydrol. 107 (1-2), 10-21.

Allan, J.D., 1995. Stream Ecology. Structure and Function of Running Waters, 1st edition. Kluwer Academic Publishers, Holland.

Ani, E.-C., Wallis, S., Kraslawski, A., Agachi, P.S., 2009. Development, calibration and evaluation of two mathematical models for pollutant transport in a small river. Environ. Modell. Softw. 24, 1139-1152.

ASTM, 2004. Standard Guide for Risk-based Corrective Action, E2081-00 (Reapproved). American Society for Testing and Materials, ASTM International, West Conshohocken, PA.

ATSDR, 1997. Toxicological Profile for Trichloroethylene. U.S. Department of Health and Human Services, Agency for Toxic Substances and Disease Registry, Division of Toxicology, Atlanta, GA.

Bruun, S., Rose, J., 2005. Påvirkning af vandløb fra punktforurenet grundvand. PreMasters Thesis. Institute for Environmental Engineering, Technical University of Denmark, Kgs. Lyngby, Denmark.

Christensen, S.B., Raun, K.D., 2005. Udsivning af punktkildeforurenet grundvand til overfladevand i et Vandrammeperspektiv. Master's Thesis. Institute for Environmental Engineering, Technical University of Denmark, Kgs. Lyngby, Denmark.

Christensen, T.H., Lehmann, N.,Jackson, T., Holm, P.E., 1996. Cadmium and nickel distribution coefficients for sandy aquifer materials. J. Contam. Hydrol. 24, 75-84.

Dall, P.C., Lindegaard, C., 1995. An Overview of Danish Freshwater Invertebrates for Assessment of Stream and Lake Contamination. Freshwater Biology Laboratory, Department of Biology, University of Copenhagen.

Eberhardt, C., Grathwohl, P., 2002. Time scales of organic contaminant dissolution from complex source zones: coal tar pools vs. blobs. J. Contam. Hydrol. 59, 45-66.

ECETOC, 2001. Exposure Factors Sourcebook for European Populations (with Focus on UK Data), Technical Report 79. European Centre for Ecotoxicology and Toxicology of Chemicals, Brussels, ISSN: 0773-8072-79.

Ellis, P.A., Rivett, M.O., 2007. Assessing the impact of VOC-contaminated groundwater on surface water at the city scale. J. Contam. Hydrol. 91, 107-127.

GEO, 2009. Lille Skensved, grundvandsforurening med chlorerede opløsningsmidler. Vurdering af afvaergeanlaeg, GEO projekt nr. 31817 , Rapport 1, 2009-02-04.

Guilbeault, M.A., Parker, B.L., Cherry, J.A., 2005. Mass and flux distributions from DNAPL zones in sandy aquifers. Ground Water 43 (1), 70-86.

Hancock, P.J., 2002. Human impacts on the stream-groundwater exchange zone. Environ. Manage. 29, 763-781.

Heathwaite, A.L., Dils, R.M., Liu, S., Carvalho, L., Brazier, R.E., Pope, L., Hughes, M., Phillips, G., May, L., 2005. A tiered risk-based approach for predicting diffuse and point source phosphorus losses in agricultural areas. Sci. Total Environ. 344, 225-239.

Henriksen, H.J., Troldborg, L., Hoejberg, A.L., Refsgaard, J.C., 2008. Assessment of exploitable groundwater resources of Denmark by use of ensemble resource indicators and a numerical groundwater-surface water model. J. Hydrol. 348, 224-240.

Huntley, D., Beckett, G.D., 2002. Persistence of LNAPL sources: relationship between risk reduction and LNAPL recovery. J. Contam. Hydrol. 59, 3-26.

IARC, 2008. IARC Monographs on the Evaluation of Carcinogenic Risks to Humans. Internal Report 08/001, Report of the Advisory Group to Recommend Priorities for IARC Monographs during 2010-2014. International Agency for Research on Cancer, World Health Organization, Lyon, France.

Kannan, N., White, S.M., Whelan, M.J., 2007. Predicting diffuse-source transfers of surfactants to surface waters using SWAT. Chemosphere 66, 1336-1345.

Kegley, S.E., Hill, B.R., Orme, S., Choi, A.H., 2008. PAN Pesticide Database - Chemicals. Pesticide Action Network, North America, San Francisco, CA, Available: http://www.pesticideinfo.org [August 11, 2009].

Klenk, I.D., Grathwohl, P., 2002. Transverse vertical dispersion in groundwater and the capillary fringe. J. Contam. Hydrol. 58, 111-128.

Mayer, A.S., Hassanizadeh, M., 2005. Soil and Groundwater Contamination: Nonaqueous Phase Liquids. American Geophysical Union, Washington, DC.

McKnight, U.S., 2009. A System Dynamics Approach for the Integrative Assessment of Contaminated Land Management Options. PhD Thesis. Tübinger Geowissenschaftliche Arbeiten (TGA), Reihe C: Hydro-, Ingenieur-, und Umweltgeologie, Center for Applied Geoscience, Eberhard-Karls-Universität Tübingen, C114, Tübingen, Germany.

McKnight, U.S., Finkel, M., 2008. Model-based Preliminary Assessment of Mega-site Management Options: A New Approach to Improve Tiered Decision-Making. IAHS Red Book Series 324, pp. 499-506.

Miljøstyrelsen, 1998. Oprydning fra forurenede lokaliteter. Vejledning fra Miljøstyrelsen, nr. 5 1998. Danish Environmental Protection Agency.

Miljø-og Energiministeriet, 1996. Bekendtgørelse om kvalitetskrav for vandområder og krav til udledning af visse farlige stoffer til vandløb, søer eller havet. BEK nr. 921 af 08/10/1996 (Gaeldende). Danish Ministry for Environment and Energy.

Møhlenberg, F., Kaas, H., Schlüter, L., Gustavson, K., Andersen, T.T., Forbes, V., Cold, A., Friberg, N., Larsen, S.E. Lauridsen, R.B., 2004. Effects of biocides and pesticides on flora and fauna in streams. Bekaempelsesmiddel-forskning fra Miljøstyrelsen No. 82, Danish Ministry for Environment and Energy.
Park, R.A. Clough, JS, 2004. AQUATOX (Release 2): Modeling Environmental Fate and Ecological Effects in Aquatic Ecosystems. Technical Documentation, EPA/823/R-04/002. Office of Water, United States Environmental Protection Agency, Washington, DC.

Park, R.A., Clough, J.S., Wellman, M.C., 2008. AQUATOX: modeling environmental fate and ecological effects in aquatic ecosystems. Ecol. Model. 213,1-15.

Peter, A., Miles, B., Teutsch, G., 2008. Estimation of emission from an LNAPL contaminated zone considering groundwater recharge. Environ. Geol. 55, 321-337.

RAIS, 2009. Chemical-specific Toxicity Values. Risk Assessment Information System, Oak Ridge National Laboratory, U.S. Department of Energy, Available: http://rais.ornl.gov/tox/tox_values.shtml [August 11, 2009].

Rathbun, R.E., 2000. Transport, behaviour, and fate of volatile organic compounds in streams. Crit. Rev. Environ. Sci. Technol. 30 (2), 129-295.

Refsgaard, J.C., van der Sluijs, J.P., Hojberg, A.L., Vanrolleghem, P.A., 2007.Uncertainty in the environmental modelling process-a framework and guidance. Environ. Modell. Softw. 22 (11), 1543-1556.

Rippen, G., 1995. Trichlorethylene, Ergänzungslieferung 31. 17/95. Handbuch Umwelt-Chemikalien: Stoffdaten, Prüfverfahren, Vorschriften. 3. Auflage mit 71. Ergänzungslieferung. Band 1-9. andsberg/Lech, Ecomed Sicherheit. Verlagsgruppe Hüthig Jehle Rehm Gmbh, 1990-2005.

Sauty, J.P., 1980. An analysis of hydrodispersive transfer in aquifers. Water Resour. Res. $16(3 / 4), 145-158$.

Scheutz, C., Durant, N.D., Dennis, P., Hansen, M.H., Jørgensen, T., Jakobsen, R., Cox, E.e., Bjerg, P.L., 2008. Concurrent ethene generation and growth of dehalococcoides containing vinyl chloride reductive dehalogenase genes during an enhanced reductive dechlorination field demonstration. Environ. Sci. Technol. 42 (24), 9302-9309.

Scholten, H., Kassahun, A., Refsgaard, J.C., Kargas, T., Gavardinas, C., Beulens, A.J.M., 2007. A methodology to support multidisciplinary model-based water management. Environ. Modell. Softw. 22, 743-759.

Serapiglia, F., Sievers, J., Finkel, M., 2005. Risk-based Design of Cost-efficient Remediation Strategies at Megasites. IAHS Red Book Series 297, pp. 249-255.

Strenge, D.L., Smith, M.A., 2006. Multimedia Environmental Pollutant Assessment System (MEPAS): Human Health Impact Module Description. PNNL-16164. Pacific Northwest National Laboratory, Prepared for the U.S. Department of Energy, Contract DE-AC06-76RLO 1830.

Stroo, H.F., Unger, M., Ward, C.H., Kavanaugh, M.C., Vogel, C., Leeson, A., Marqusee, J.A., Smith, B.P., 2003. Remediating chlorinated solvent source zones. Environ. Sci. Technol. 37 (11), 224A-230A.

Tannenbaum, L.V., 2005. A critical assessment of the ecological risk assessment process: a review of misapplied concepts. Integr. Environ. Assess. Manage. 1, 66-72.

Troldborg, M., Lemming, G., Binning, P.J., Tuxen, N., Bjerg, P.L., 2008. Risk assessment and prioritisation of contaminated sites on the catchment scale. J. Contam. Hydrol. 101, 14-28.

U.S. EPA, 1991. Risk Assessment Guidance for Superfund: Volume I - Human Heath Evaluation Manual (Part B, Development of Risk-based Preliminary Remediation Goals). EPA/540/R-92/003. United States Environmental Protection Agency, Office of Emergency and Remedial Response, Washington, DC.

U.S. EPA, 1997a. Ecological Risk Assessment Guidance for Superfund: Process for Designing and Conducting Ecological Risk Assessments. Interim Final. United States Environmental Protection Agency, Environmental Response Team, Edison, NJ.

U.S. EPA, 1997b. Exposure Factors Handbook, Volumes I-III. EPA/600/P95/002Fa,b,c. United States Environmental Protection Agency, Office of Research and Development, Washington, DC.

U.S. EPA, 2001. Appendix Q: Human Health Benchmarks. United States Environmental Protection Agency, Office of Solid Waste, Washington, DC.

U.S. EPA, 2004. Risk Assessment Guidance for Superfund: Volume I - Human Heath Evaluation Manual (Part E, Supplemental Guidance for Dermal Risk Assessment). OSWER 9285.702EP. United States Environmental Protection Agency, Office of Superfund Remediation and Technology Innovation, Washington, DC.

U.S. EPA, 2009a. ECOTOX Database. United States Environmental Protection Agency, Available: http://www.epa.gov/med/Prods_Pubs/ecotox.htm [August 11, 2009].

U.S. EPA, 2009b. Integrated Risk Information System (IRIS). United States Environmental Protection Agency, Available: http://www.epa.gov/ncea/ iris/help_start.htm [August 11, 2009].

U.S. EPA, 2009c. Water Quality Models and Tools. United States Environmental Protection Agency, Available: http://www.epa.gov/waterscience/models/aquatox/ [August 11, 2009].

van Groenendaal, W.J.H., Kleijnen, J.P.C., 2002. Deterministic versus stochastic sensitivity analysis in investment problems: an environmental case study. Eur. J. Oper. Res. 141, 8-20.

Ventana Systems, 2007. Vensim Simulation Environment - User's Guide, Revision date: July 4, 2007. Ventana Systems, Inc., Harvard (MA), USA.

Winter, T.C., Harvey, J.W., Franke, O.L., Alley, W.M., 1998. Ground Water and Surface Water: A Single Resource. U.S. Geol. Surv. Circ. 1139.

$\mathrm{Xu}, \mathrm{M}$. , Eckstein, Y., 1995. Use of weighted least-squares method in evaluation of the relationship between dispersivity and scale. Ground Water 33 (5), 905-908. 